\title{
Aphis craccivora Koch, 1854 (Hemiptera: Aphididae) infesting mahogany seedlings (Swietenia macrophylla King, Meliaceae) and scarlet jade vines (Mucuna bennettii F. Muell., Fabaceae)
}

\author{
Marcelo T. Castro ${ }^{1 \pm=}\left(\mathbb{\infty}\right.$, Sandro C. L. Montalvão ${ }^{2}$, Suzan B. Z. Cunha ${ }^{3 \oplus}$, Rose G. Monnerat ${ }^{2}$
}

${ }^{1}$ Centro Universitário ICESP de Brasilia, Distrito Federal, Brazil. ${ }^{2}$ Embrapa Recursos Genéticos e Biotecnologia, Distrito Federal, Brazil. ${ }^{3}$ Universidade Federal de São Carlos, São Paulo, Brazil.

拝='Corresponding author: marceloengflorestal@gmail.com

Edited by: Elio C. Guzzo

Received: March 01, 2020. Accepted: June 15, 2020. Published: July 20, 2020.

\begin{abstract}
Aphis craccivora Koch, 1854 (Hemiptera: Aphididae) is a highly polyphagous aphid that is considered a pest of many crops with economic interest. The present study reports the occurrence and plant damages caused by the aphid A. craccivora on mahogany seedlings (Swietenia macrophylla King, Meliaceae) and scarlet jade vines (Mucuna bennettii F. Muell., Fabaceae) in the Distrito Federal, Brazil. Infestations of this aphid were found in twelve mahogany seedlings and two scarlet jade vines. The infestations caused deformations in the young leaflets of mahogany plants as well as leaves and inflorescences of scarlet jade vine. A. craccivora negatively affected the development of $S$. macrophylla and might become a limiting factor for seedlings production.
\end{abstract}

Keywords: Aphididae, Hemiptera, Forest Entomology, Phytophagous Insect.

Mahogany (Swietenia macrophylla King, Meliaceae) from the Amazon has wood with high commercial value. The species is widely used in landscaping, including the afforestation of several cities (Carvalho 2007) and in programs to recover degraded areas. For the installation of mahogany cultivation to be successful, quality seedlings are essential. Pests and diseases can negatively affect the development of plants, hampering production and making the use of some seedlings impossible. Some arthropods have been observed to damage young mahogany plants, including scale insects and mites (Castro et al. 2018; 2019a; 2019b; 2020).

Scarlet jade vine (Mucuna bennettii F. Muell., Fabaceae) is an exotic ornamental vine very common in several Brazilian regions and is one of the most used vines for landscaping in urban environments (Fenyö 2013; Lorenzi 2013). This perennial and robust plant exhibits long and showy inflorescences, of the raceme type, pendants, and bright reddish coloration (Lorenzi 2013). It can be found in several points of Brasilia, including in local florists. So far, there are no records of insects associated with this species in Brazil.

The present study reports the occurrence and plant damages caused by the aphid Aphis craccivora Koch, 1854 (Hemiptera: Aphididae) on mahogany seedlings and scarlet jade vines in the Distrito Federal, Brazil.

Aphids infesting twelve mahogany seedlings about one month old and two scarlet jade vines, planted next to mahogany seedlings, were collected in October 2019 in Distrito Federal, Brazil (15'56'55.2"S $\left.48^{\circ} 10^{\prime} 00.8^{\prime \prime} \mathrm{W}\right)$. The seedlings of mahogany were produced outdoors in plastic trays containing a mixture of soil with Plantmax ${ }^{\circledR}$ substrate. No pesticides were applied during seedling production. Both jade vines were planted in June 2017 using two pits $30 \mathrm{~cm}$ deep. Subsequently, they were fertilized with matured cattle manure immediately after they were transplanted and one year after transplanting. The seedlings were watered daily for the first few weeks and then weekly.

The aphids collected in mahogany and red jade were fixed in Falcon ${ }^{\circledR}$ tubes containing $70 \%$ alcohol, subsequently mounted on microscope slides, following the methodology described by Ilharco \& Gomes (1981) and identified with the aid of a microscope using a taxonomic key proposed by Holman (1974). The insects are deposited in the Collection of aphids - COLEAFIS - of the Laboratory of Applied Entomology (LEA), Department of Ecology and Evolutionary Biology (DEBE) of the Federal University of São Carlos (UFSCar) under the numbers 1541 (from mahogany) and 1542 (from red jade).

The aphids collected from the two host plants were identified as A craccivora. The aphids were observed covering a large part of the top of the twelve mahogany seedlings, infesting newer leaves and buds (Fig. 1), causing leaflet curl and deformation in the apical bud.

In scarlet jade vine, A. craccivora attacked mainly new shoots, causing deformities in newly emerged buds and leaves (Fig. 2). In addition, the aphid was observed on flower buds in large quantities, resulting in an abundant release of honeydew, making the flower stems sticky and with a light presence of the fungus Capnodium sp., which causes sooty mold. Some natural enemies, such as larvae and adults of Cycloneda sanguinea (Linnaeus, 1763) (Coleoptera: Coccinellidae) and larvae of Syrphidae (Diptera), were observed feeding on aphids during the execution of this study.

The suborder Sternorrhyncha (Hemiptera) includes small insects commonly known as scale insects, aphids, whiteflies, and psyllids and are all phytophagous, most feeding on the phloem of angiosperms and some gymnosperms (Carver et al. 1991). The Aphidoidea superfamily is home to aphids, which are small, soft-bodied insects often found in large colonies. These insects have great economic importance, especially in the agricultural area, due to their intense sap sucking and ability to transmit pathogens, mainly viruses (NG \& Perry 2004; Triplehorn \& Johnson 2011; Fujihara et al. 2016).

Aphis craccivora is a polyphagous and cosmopolitan aphid with the highest occurrence in plants of the Leguminosae family; however, it has already been observed in association with more than 50 botanical families (Blackman \& Eastop 2007; 2020). In Brazil, this aphid is considered an important cowpea pest (Silva et al. 2005) and was recently described in association with the Dalbergia miscolobium Benth. (Leguminosae), a tree species native to the Brazilian Cerrado (Castro et al. 2019c).

Several species of polyphagous aphids colonize species of the 


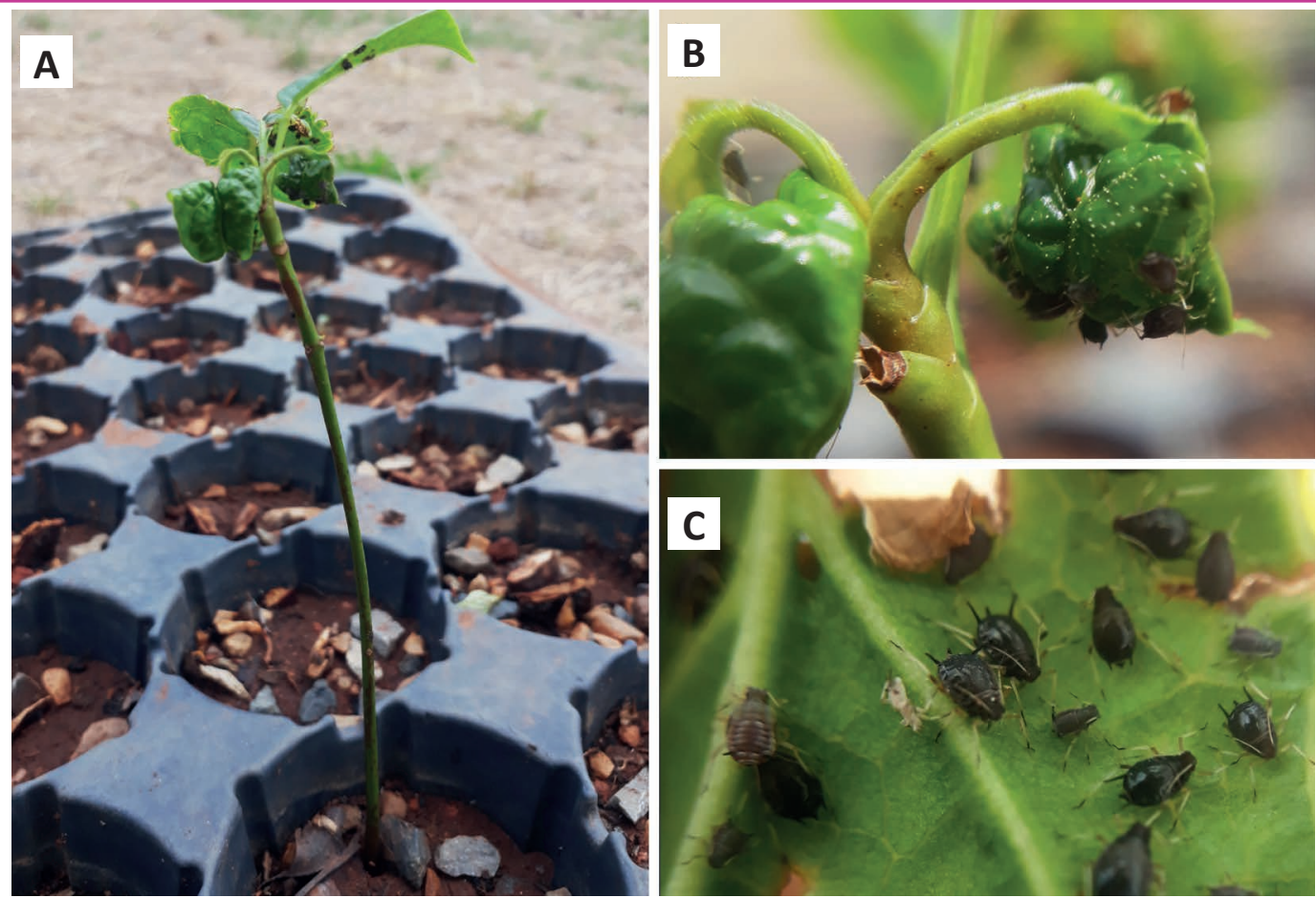

Figure 1. Aphis craccivora infesting seedlings of mahogany (Swietenia macrophylla). A - S. macrophylla seedling attacked by the aphid. B - Rolled up leaflets caused by A. craccivora. C - Detail of A. craccivora on mahogany leaves.
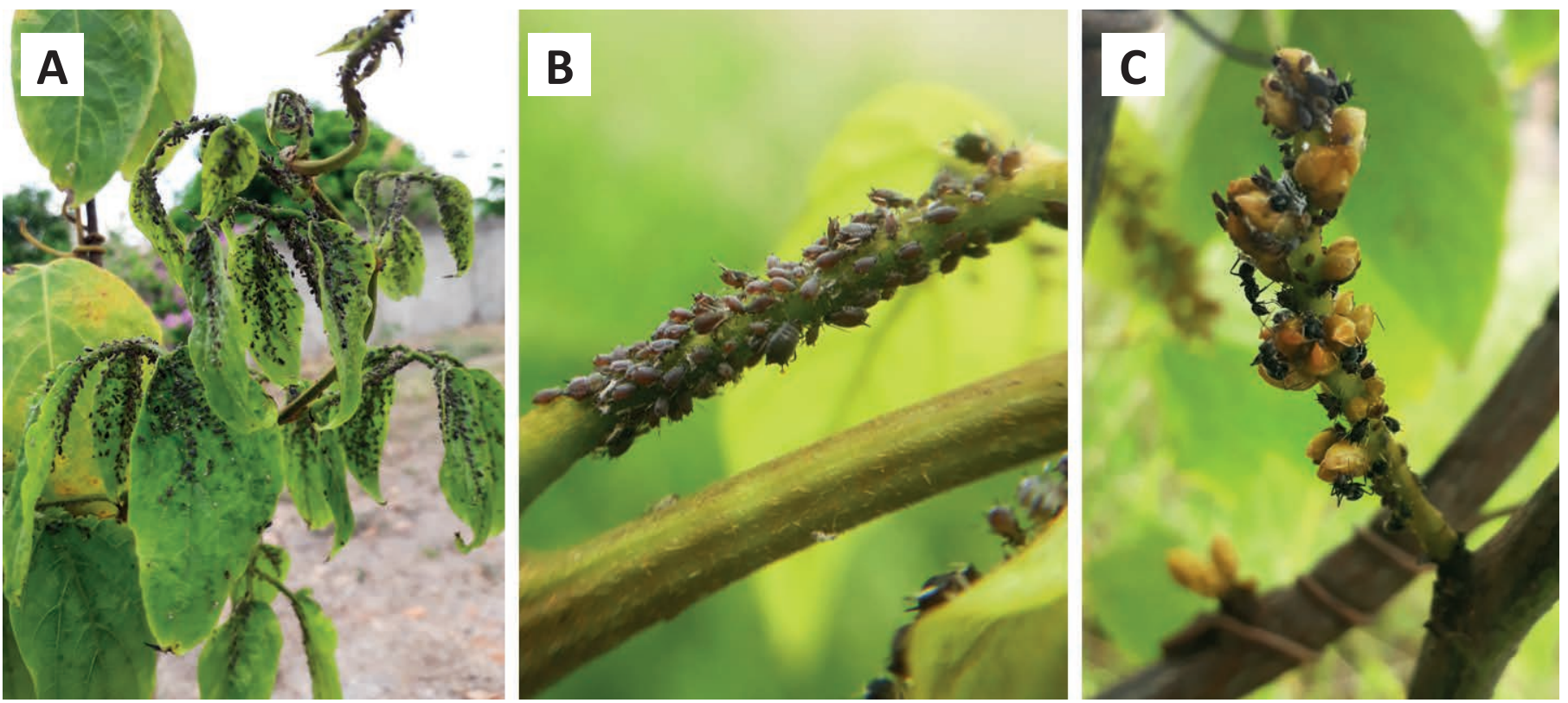

Figure 2. Aphis craccivora infesting plants of scarlet jade vine (Mucuna bennettii). A - Scarlet jade vine attacked by the aphid. B - Detail of A. craccivora colony on a branch of scarlet jade. C - A. craccivora in scarlet jade inflorescence.

genus Mucuna around the world (Blackman \& Eastop 2020). In Brazil, occurrence of $A$. craccivora and Aphis fabae Scopoli, 1763 has been reported on M. pruriens (Sousa-Silva \& Ilharco 1995), aphids have never been associated with $M$. bennettii.

No aphid species had ever been reported in association with genus Swietenia in the world (Blackman \& Eastop 2020); thus, its occurrence on S. macrophylla was unprecedented. A. craccivora negatively affected the development of $S$. macrophylla and might become a limiting factor for producing seedlings of this species in the Cerrado region.

\section{Author's Contributions}

MTC: Performed the material collection and analysis; wrote the manuscript. SCLM: Performed the material collection and analysis; wrote the manuscript. SBZC: Performed the analysis; wrote the manuscript. RGM: Contributed to the interpretation of the results.

\section{References}

Blackman, R. L.; Eastop, V. F. (2007) Taxonomic Issues. In: Van Emden, H. F.; Harrington, R. (Eds.), Aphids as Crop Pests, pp. 1-30. Wallingford: CABI Publishing.

Blackman, R. L.; Eastop, V. F. (2020) Aphids on the world's plants: An online identification and information guide. http://www.aphidsonworldsplants.info. Access on: i.2020.

Carvalho, P. E. R. (2007) Mogno - Swietenia macrophylla. Circular Técnica 140. Colombo: Embrapa Florestas. https://ainfo. cnptia.embrapa.br/digital/bitstream/CNPF-2009-09/42435/1/ Circular140.pdf. Access on: 12.vi.2020.

Castro, M. T.; Montalvão, S. C. L.; Monnerat, R. G.; Prado, E.; Picanço, M. C.; Peronti, A. L. B. G. (2018) First report of Saissetia miranda (Cockerell \& Parrott) (Hemiptera: Coccidae) in Brazil: occurrence on mahogany seedlings. Florida Entomologist, 101(2): 324-326. doi: 10.1653/024.101.0227 
Castro, M. T.; Montalvão, S. C. L.; Peronti, A. L. B. G.; Monnerat, R. G. (2019a) Ocorrência da cochonilha Phenacoccus solenopsis Tinsley (Hemiptera: Pseudococcidae) em mudas de mogno (Swietenia macrophylla King). EntomoBrasilis, 12(1): 41-43. doi: 10.12741/ ebrasilis.v12i1.791

Castro, M. T.; Montalvão, S. C. L.; Navia, D.; Flechtmann, C. H. W.; Monnerat, R. G. (2019b) First report of Eutetranychus banksi (McGregor) on mahogany (Swietenia macrophylla King). Floresta e Ambiente, 26(4): 1-4. doi: 10.1590/2179-8087.119617

Castro, M. T.; Montalvão, S. C. L. (2019c) Ocorrência e controle do pulgão-preto, Aphis craccivora Koch (Hemiptera: Aphididae), em mudas de jacarandá-do-cerrado (Dalbergia miscolobium Benth.) com o uso de detergente neutro. EntomoBrasilis, 12(3): 154-156. doi: 10.12741/ebrasilis.v12i3.865

Castro, M. T.; Montalvão, S. C. L.; Wolff, V. R. S.; Monnerat, R. G. (2020) Occurrence of greedy scale, Hemiberlesia rapax (Comstock) (Hemiptera: Diaspididae), on mahogany in Brazil. Pesquisa Agropecuária Gaúcha, 26(1): 1-6. doi: 10.36812/pag.20202611-6

Carver, M.; Gross, G. F.; Woodward, T. E. (1991) 30 - Hemiptera. In: Naumann, I. D.; Carne, P. B.; Lawrence, J. F.; Nielson, E. S.; Spradbery, J. P. (Eds.), The insects of Australia, pp. 429-515. New York: Cornell University Press.

Fenyö, C. (2013) Trepadeiras - Soluções Criativas. Coleções Natureza. São Paulo: Editora Europa.

Fujihara, R. T.; Forti, L. C.; Almeida, M. C.; Baldin, E. L. L. (2016) Insetos de importância econômica: guia ilustrado para identificação de familias. Botucatu: FEPAF.

Holman, J. (1974) Los áfidos de Cuba. La Habana: Editorial Organismos.

Ilharco, F. A.; Gomes, A. (1981) Montagem de afídeos para observação microscópica. Introdução de uma nova operação. Agronomia Lusitana, 28: 41-45.

Lorenzi, H. (2013) Plantas para jardim no Brasil: herbáceas, arbustivas e trepadeiras. Nova Odessa, São Paulo: Plantarum.

NG, J. C. K.; Perry, K. L. (2004) Transmission of plant viruses by aphid vectors. Molecular Plant Pathology, 5: 505-511. doi: 10.1111/j.1364-3703.2004.00240.x

Silva, P. H. S.; Carneiro, J. S.; Quinderé, M. A. W. (2005) Pragas, In: Freire Filho, F. R.; Lima, J. A. A.; Ribeiro, V. Q. Feijão caupi: Avanços tecnológicos, pp. 369-402. Brasília: Embrapa.

Sousa-Silva, C. R.; Ilharco, F. A. (1995) Afídeos do Brasil e suas plantas hospedeiras (lista preliminar). São Carlos: EDUFSCar.

Triplehorn, C. A.; Johnson, N. F. (2011) Estudo dos insetos. (Ed.): Borror and Delong's Introductions to the Study of Insects. São Paulo: Cengage Learning. 